\title{
Chasing Warblers
}

Number Forty

The Corrie Herring Hooks Series 


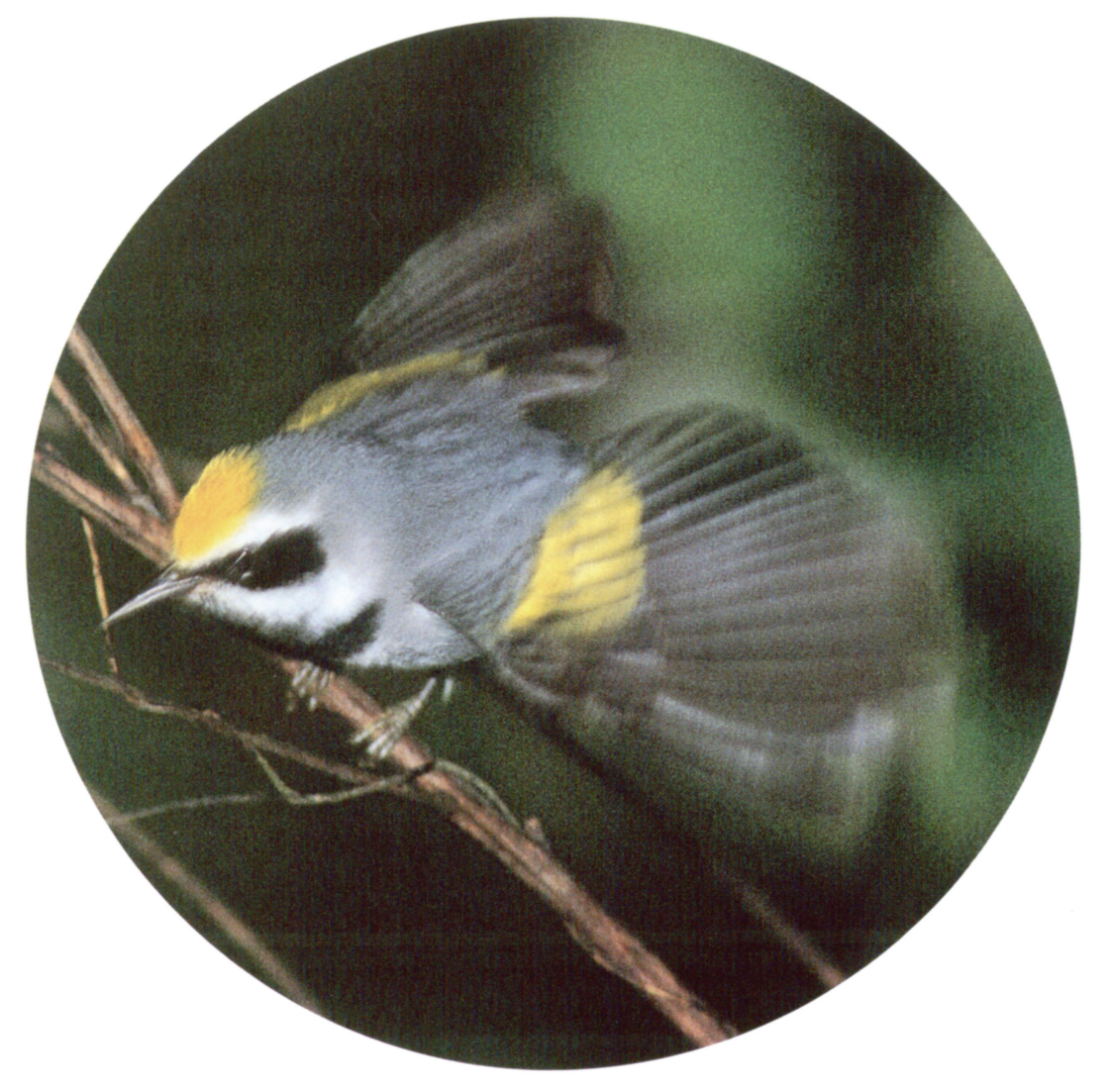




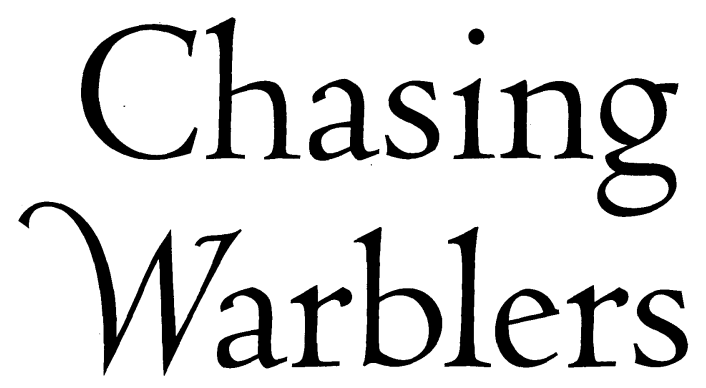

\author{
Text by Bob Thornton \\ Photograpby by
}

Vera and Bob Thornton

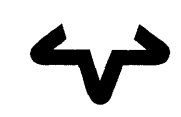

University of Texas Press

Austin 
Copyright (C) 1999 by Vera Thornton and Bob Thornton All rights reserved

Printed in China

First edition, 1999

Requests for permission to reproduce material from this work should be sent to Permissions, University of Texas Press, Box 7819, Austin, TX 78713-7819.

LIBRARY OF CONGRESS

CATALOGING-IN-PUBLICATION DATA

Thornton, Bob, 1940-

Chasing warblers / text, Bob Thornton ; photography,

Vera and Bob Thornton. - ist ed.

p. cm. - (The Corrie Herring Hooks series ;

no. 40)

Includes bibliographical references ( $p$. ) and index.

ISBN 0-292-78162-8 (alk. paper)

ISBN o-292-78163-6 (pbk. : alk. paper)

1. Wood warblers-Migration. 2. Wood WarblersMigration-Pictorial works. I. Title. m. Series. QL696.P2438 T48 1999

$598.8^{\prime} 721568-\mathrm{ddc}^{2} 1$ $98-25415$

ISBN 9780292758377 (library e-book)

ISBN 9780292785687 (individual e-book) 
$E$ dedicate this book to the core principles of conservation and to those who are committed to preserving critical habitat so necessary to the health and survival of our American songbirdslike the North American Wood Warblers. 
